\title{
Larvicidal effect of Prosopis juliflora on Aedes aegypti (Diptera: Culicidae)
}

The aim of this work was to evaluate the larvicidal effect of aqueous extracts of Prosopis juliflora on A. aegypti. Oviposition traps (ovitramps) were used to obtain the insect's eggs. The test was carried out at the Agricultural Entomology Laboratory of the Federal University of Cariri, Crato, Ceará, Brazil, with controlled temperature, humidity and photophase, using larvae in the 30 instar. The design used was completely randomized with five doses (10, 20, 30, 40 and $50 \mathrm{~g} L-1)$ of the aqueous extract plus two control treatments (pyriproxifene at $0.01 \mathrm{~g} \mathrm{L-1}$ and distilled water). The treatments were evaluated after $24,48,72,96,120,144$ and $168 \mathrm{~h}$ of exposure of the larvae, being considered dead those that did not react to the mechanical stimulus of a clamp. The doses of 40 and $50 \mathrm{~g} L-1$ of $\mathrm{P}$. juliflora are effective in the mortality of A. aegypti larvae after $48 \mathrm{~h}$ of exposure, with greater efficiency ( $100 \%$ mortality) after $120 \mathrm{~h}$. The lowest doses (10 and $20 \mathrm{~g}$ L- 1 ) have low mortality efficiency, while the dose of $30 \mathrm{~g} \mathrm{~L}-1$ causes satisfactory mortality after $148 \mathrm{~h}$ of exposure. The aqueous extract of the leaves of P. Juliflora (in doses of 40 and $50 \mathrm{~g} \mathrm{L-1}$ ) is effective in controlling A. aegypti.

Keywords: Algaroba; Botanical Insecticide; Dengue; Secondary Metabolites.

\section{Efeito larvicida de Prosopis juliflora sobre Aedes aegypti (Diptera: Culicidae)}

\begin{abstract}
O objetivo deste trabalho foi avaliar o efeito larvicida de extratos aquosos de Prosopis juliflora sobre A. aegypti. Armadilhas de oviposição (ovitramps) foram utilizadas para a obtenção dos ovos do inseto. O teste foi realizado no Laboratório de Entomologia Agrícola da Universidade Federal do Cariri, Crato, Ceará, Brasil, com temperatura, umidade e fotofase controladas, utilizando larvas de 30 ínstar. O delineamento utilizado foi inteiramente casualizado com cinco doses $(10,20$, 30,40 e $50 \mathrm{~g} \mathrm{~L}-1$ ) do extrato aquoso mais dois tratamentos controle (piriproxifeno 0,01g L-1 e água destilada). Os tratamentos foram avaliados após $24,48,72,96$, 120, 144 e $168 \mathrm{~h}$ de exposição das larvas, sendo considerados mortos aqueles que não reagiram ao estímulo mecânico de uma pinça. As doses de 40 e $50 \mathrm{~g} \mathrm{~L}-1$ de P. juliflora são eficazes na mortalidade de larvas de A. aegypti após $48 \mathrm{~h}$ de exposição, com maior eficiência ( $100 \%$ mortalidade) após $120 \mathrm{~h}$. As menores doses (10 e $20 \mathrm{~g} \mathrm{~L}-1$ ) apresentam baixa eficiência de mortalidade, enquanto a dose de $30 \mathrm{~g} \mathrm{L-1}$ causa mortalidade satisfatória após $148 \mathrm{~h}$ de exposição. 0 extrato aquoso das folhas de P. Juliflora (nas doses de 40 e $50 \mathrm{~g} \mathrm{~L}-1$ ) é eficaz no controle de A. aegypti.
\end{abstract}

Palavras-chave: Algaroba; Inseticida botânico; Dengue; Metabólitos secundários.

Topic: Desenvolvimento, Sustentabilidade e Meio Ambiente

Reviewed anonymously in the process of blind peer.
Received: 04/02/2021

Approved: 25/02/2021
Francisco Roberto de Azevedo (it) Universidade Federal do Cariri, Brasil http://lattes.cnpq.br/7232754070890745 http://orcid.org/0000-0002-6953-6175 roberto.azevedo@ufca.edu.br

Gabriel dos Santos de Oliveira (ib Universidade Federal do Cariri, Brasil http://lattes.cnpq.br/5697255822753343 http://orcid.org/0000-0002-0024-7439 gabriel@bol.com.br

Eridiane da Silva Moura (iD Universidade Federal do Cariri, Brasil http://lattes.cnpq.br/0289811423627249 http://orcid.org/0000-0002-3233-7033 annne.moura@gmail.com

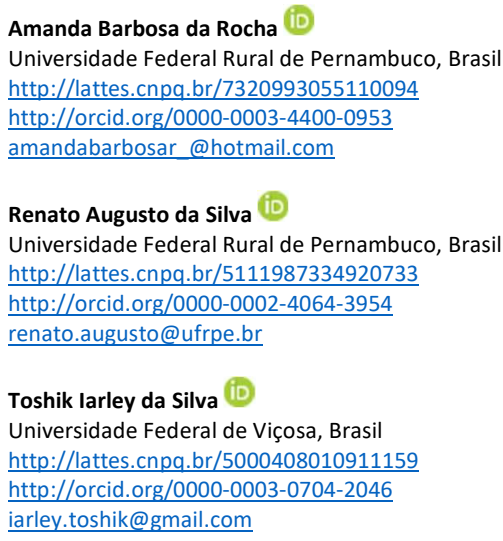

Francisco de Oliveira Mesquita (iD) Instituto Nacional do Semiárido, Brasil http://lattes.cnpq.br/2630263044186621 http://orcid.org/0000-0002-8580-079X mesquitaagro@yahoo.com.br 


\section{INTRODUCTION}

Aedes aegypti L., is a mosquito that causes serious problems to human health, transmitting the virus from four important diseases: yellow fever, dengue, chikungunya and zika (SCOLARI et al., 2019). This vector is widely distributed, carrying out its activities at the same times and environments as the human population (BENNETT et al., 2019). Transmission occurs due to the bite of the female mosquito infected with the DEN virus during blood meal (SCOLARI et al., 2019). Annually, about 50-100 million people worldwide are infected with these four types of viruses and about three billion people are at risk of becoming infected, particularly in tropical countries (WHO, 2011).

The spread of these diseases is considered to be one of the most serious public health problems in the world and can be explained in part by an intensification of conditions favorable to the dispersion and proliferation of $A$. aegypti as a result of global trade and unplanned urbanization; inefficient implementation of vector control programs due to inadequate human, financial and infrastructure capabilities; irregular supply and irregular water storage practices and ineffective waste disposal (LINDSAY et al., 2017).

The main corn producing states are: Mato Grosso, with an index of 20 million tons in the 2015/2016 harvest, followed by Parana, with 16.2 million tons, Mato Grosso do Sul, with 8.3 million tons, Goias, with 7.7 million tons, Minas Gerais, with 7.0 million tons and Rio Grande do Sul, with 6.0 million tons (IBGE, 2017).

The prevention or reduction of diseases caused by viruses transmitted by $A$. aegypti continues to depend largely on the control of mosquito populations or the interruption of human-vector contact (ROIZ et al., 2018). The use of chemical insecticides is still the main measure to control vector mosquitoes (ESTRADA et al., 2019), but their use in high doses and number of applications, in addition to causing problems to human and environmental health (POLANCZYK et al., 2013), causes an increase in the resistance of vectors in relation to the insecticides used (ESTRADA et al., 2019).

Vegetable insecticides are promising alternatives for vector control, as they are biodegradable and rich in compounds with diverse biological activities, in addition to offering less risk to human health (VARUN et al., 2013). The mesquite tree [Prosopis juliflora (Sw.) DC.] Is a tree in the family Leguminoseae and subfamily Mimosoideae. This species is cultivated in Brazil mainly in the Northeast region, due to its adaptation to the climatic conditions of the northeastern semiarid, resisting long droughts (RIBASKI et al., 2009). Considered a multi-purpose tree, it has proven importance for reforestation due to its capacity to resist drought, in addition to producing good quality wood for various purposes (PASIECZNIK et al., 2001), providing soil protection against erosion, shading, conservation and improvement of pastures and support for beekeeping (CHAPMAN et al., 2019).

A. aegypti is the cause of several diseases, becoming a social and economic problem, requiring alternatives for its control. Thus, the objective of this work was to evaluate the larvicidal effect of aqueous extracts of Prosopis juliflora on A. aegypti. 


\section{MATERIALS AND METHODS}

Installation of traps

Oviposition traps (ovitramps), with water and $10 \%$ fermented hay, were installed in ten districts of the city of Crato, Ceara, to obtain the eggs of $A$. aegypti. The traps were removed after five days of installation and the straws with the eggs were immersed in water (from the municipal supply system) for hatching of the larvae. The hatched larvae remained in the trays with water and were fed with fish food (Alcon Pet, Santa Catarina, Brazil) until the third instar.

\section{Obtaining plant material}

The aerial parts of $P$. Juliflora were collected at the Xavier site, a rural area in the interior of Paraiba, located in the city of Juru - Paraíba, coordinates Lat. -7.567537/Log. -37.812334, in September 2018 in the morning. The collected material was stored in paper bags and sent to the Chemistry Laboratory (LAQUIM) of the Serra Talhada Academic Unit (UAST), Federal Rural University of Pernambuco (UFRPE). These aerial parts were treated in the New Lab drying oven at a temperature of $45 \circ \mathrm{O}$ for $48 \mathrm{~h}$. The dried leaves of $P$. Juliflora were separated from the petiole and then crushed in a domestic blender. The powder was finally obtained after treatment with an ASTM 18 TYLER/MESH 16 granulometric sieve and, soon after, it was stored in a properly closed plastic container.

\section{Preparation of aqueous extract}

The larvicidal assay was carried out at the Agricultural Entomology Laboratory of the Federal University of Cariri, in 2018, at the Center for Agricultural and Biodiversity Sciences, in county of Crato, Ceara, Brazil. The experiment was conducted in a B.O.D. (Eletrolab, EL202, São Paulo, Brazil) with controlled temperature $\left(25 \pm 1^{\circ} \mathrm{C}\right)$, relative humidity $(70 \pm 10 \%)$ and photophase $(12 \mathrm{~h})$. The species was identified by professor PhD Andre Laurênio de Melo (UFRPE), from the botany department, belonging to herbarium of the Semi-Arid Region of Brazil (HESBRA) at UFRPE/UAST.

The design used was completely randomized with five doses $\left(10,20,30,40\right.$ and $\left.50 \mathrm{~g} \mathrm{~L}^{-1}\right)$ of the aqueous extract of $P$. juliflora plus two control treatments (pyriproxifene of $0.01 \mathrm{~g} \mathrm{~L}^{-1}$, dose recommended by the manufacturer and distilled water), with five repetitions of 10 larvae in each repetition.

The dry powder of the plant and the chemical insecticide were suspended with water from the municipal supply network in the doses already specified and were subjected to mechanical agitation for $1 \mathrm{~h}$. Then, the solutions were transferred to polyethylene cups with a capacity of $50 \mathrm{~mL}$ containing 10 larvae in the third instar (L3) for each treatment.

\section{Mortality efficiency}

The treatments were evaluated after $24,48,72,96,120,144$ and 168 hours of exposure of the larvae, being considered dead those that did not react to the mechanical stimulus of a clamp. 
The larval mortality efficiency was determined in percentage using the Abbott (1925) formula: $E$ (\%) $=(\mathrm{Nc}-\mathrm{Nt}) / \mathrm{Nc} \times 100$, where: $\mathrm{E}=$ mortality efficiency, $\mathrm{Nc}=$ number of individuals living in the control treatment and $\mathrm{Nt}=$ number of live individuals treated.

\section{Phytochemical analysis of aqueous extract}

The phytochemical analysis of the aqueous extract of $P$. juliflora was performed at the Chemistry Laboratory of the Federal Rural University of Pernambuco, Serra Talhada Academic Unit, using $10 \mathrm{~g}$ of the dry and crushed extract. The dry extract was placed in an Erlenmeyer and suspended with distilled water to $100 \mathrm{~mL}$ of the container. The mixture was stirred for $30 \mathrm{~min}$ and then the liquid was collected by means of simple filtration with cotton. Phytochemical tests were performed using $3 \mathrm{~mL}$ of the solution, as shown below:

Tannins - 3 drops of $2 \%$ gelatin solution saturated with $\mathrm{NaCl}$ were added and there was no precipitate.

Saponins - the tube was shaken vertically for $30 \mathrm{~min}$ and after $5 \mathrm{~min}$ the foam persisted.

Triterpenes - an extraction was performed with $\mathrm{CHCl}_{3}$. The organic phase separated from the aqueous phase was added slowly three drops of sulfuric acid. There was no color change.

Steroids - an extraction was performed with $\mathrm{CHCl}_{3}$. The organic phase separated from the aqueous phase was added $1 \mathrm{ml}$ of acetic anhydride and, slowly, three drops of sulfuric acid. There was no color change.

Phenolic compounds - three drops of $3 \% \mathrm{FeCL}_{3}$ solution were added. An upper ring with a dark bond was formed.

Flavonoids - Mg shavings were added and then, slowly, five drops of $\mathrm{HCl}$. Dark solution formation was observed.

Alkaloids - three drops of the Dragendorff reagent were added. An orange precipitate was formed. White (reference).

\section{Statistical analysis}

The toxicity data were submitted to probit analysis using the SAS software (SAS Institute, Cary, NC, USA), generating concentration-mortality curves. Mortality data were submitted to ANOVA and Tukey's test using the Statistica 8 software (StatSoft Inc, Tulsa, OK, USA).

\section{RESULTS}

The highest mortality of $A$. aegypti larvae was observed in the doses of 40 and $50 \mathrm{~g} \mathrm{~L}^{-1}$ of $P$. juliflora extract after 24 and 48 hours of exposure of the larvae, with 62 and $92 \%$ and 92 and $98 \%$ mortality, respectively. The dose of $30 \mathrm{~g} \mathrm{~L}^{-1}$ caused 52 and $60 \%$ mortality, respectively, after 24 and 48 hours of exposure. The doses of 10 and $20 \mathrm{~g} \mathrm{~L}^{-1}$ did not cause $10 \%$ mortality (Table 1 ), having low efficiency during these periods of exposure. 
Table 1: Mortality efficiency (\%) of Prosopis juliflora extract on Aedes aegypti larvae, Crato-CE, 2018.

\begin{tabular}{|c|c|c|c|c|c|c|c|c|}
\hline \multirow{3}{*}{ Treatments } & \multirow{3}{*}{ Dosages $\left(\mathrm{g} \mathrm{L}^{-1}\right)$} & \multicolumn{7}{|c|}{ Exposure periods (h) } \\
\hline & & 24 & 48 & 72 & 96 & 120 & 144 & 168 \\
\hline & & \multicolumn{7}{|c|}{ Mortality Efficiency (\%) } \\
\hline Distilled water & 0 & 0 & 0 & 0 & 0 & 0 & 0 & 0 \\
\hline Pyriproxifene & 0.01 & 58 & 70 & 75 & 77 & 76.5 & 88.2 & 95.3 \\
\hline $10 \mathrm{mg} \mathrm{L}^{-1}$ PJE & 10 & 2 & 4 & 8.3 & 16 & 17 & 17 & 29 \\
\hline $20 \mathrm{mg} \mathrm{L}^{-1}$ PJE & 20 & 4 & 6 & 16 & 24 & 41,2 & 43,5 & 50,6 \\
\hline $30 \mathrm{mg} \mathrm{L}^{-1}$ PJE & 30 & 52 & 60 & 60.4 & 63.2 & 67.1 & 74.1 & 85.9 \\
\hline $40 \mathrm{mg} \mathrm{L}^{-1}$ PJE & 40 & 62 & 92 & 95.8 & 97.7 & 97.6 & 95.3 & 96.5 \\
\hline $50 \mathrm{mg} \mathrm{L}^{-1}$ PJE & 50 & 92 & 98 & 91.7 & 97.7 & 90.6 & 97.6 & 97.6 \\
\hline
\end{tabular}

PJE = Prosopis juliflora extract.

When analyzing the efficiency of mesquite leaf post-dry, it was noticed a greater efficiency of larval mortality from $40 \mathrm{~g}$ dosage when compared to pyriproxyphene, obtaining a result similar to this chemical from $30 \mathrm{~g} \mathrm{~L}^{-1}$ dosage. It was found that the dosages of 40 and $50 \mathrm{~g} \mathrm{~L}^{-1}$ at the end of the evaluation period of 168 h (seven days), caused an efficiency of larval mortality of $96.3 \%$ and $100 \%$, respectively, while pyriproxifene caused $62.9 \%$. There is also a low efficiency of the dried leaves of the mesquite leaf in the dosages of 10 and $20 \mathrm{~g} \mathrm{~L}^{-1}$ (Table 1 ).

The Probit model was adequate for the treatment dose-mortality data after $96 \mathrm{~h}$ of exposure, based on the low value of $\chi 2$ and the high value of $P$ obtained in the post-dry curve of $P$. juliflora leaves on 3rd larvae instar of $A$. aegypti. The value of $\chi 2=0.12$ and $\mathrm{P}=0.96$ was obtained. The lethal doses to cause 50 and $95 \%$ mortality of the larvae $\left(L_{50}\right.$ and $\left.L D_{95}\right)$ were 29.8 and $49.9 \mathrm{~g} \mathrm{~L}^{-1}$ of water respectively (Table 2$)$. The slope of the curve was $(1.92 \pm 0.35)$.

Table 2: Lethal doses of dry powder of Prosopis juliflora for Aedes aegypti larvae after 96h of exposure, Crato - CE, 2018.

\begin{tabular}{llllll}
\hline Treatment & $\mathrm{LD}_{50}$ & $\mathrm{LD}_{95}$ & Inclination $\left( \pm \mathrm{EQM}^{1}\right)$ & $X^{2}(\mathrm{~d} f)$ & $P$ \\
\hline Algaroba Extract & 29,8 & 49,9 & $1.92 \pm 0.35$ & $0.12(5)$ & 0.96 \\
\hline
\end{tabular}

$\mathrm{LD}=$ Lethal Dose $\left(\mathrm{g} \mathrm{L}^{-1}\right) ; \mathrm{EQM}^{1}=$ Mean square error; $X^{2}=$ Chi square; $P=$ Probability; $\mathrm{df}=$ degrees of freedom.

Considering $168 \mathrm{~h}$ (seven days) of exposure of the larvae submitted to different dosages, it is statistically observed that there was no difference between the dosages of 30,40 and $50 \mathrm{~g} \mathrm{~L}^{-1}$ which caused an average mortality of 8.8; 9.8 and 10 larvae, respectively. The results of the phytochemical prospecting of the aqueous extract of the dry powder of the mesquite leaf indicate the presence of the metabolites saponin, phenolic, flavonoids and alkaloids (Table 3).

Table 3: Preliminary phytochemical prospecting of the aqueous extract of Prosopis juliflora, Serra Talhada-PE, 2018.

\begin{tabular}{lll}
\hline Metabolite class & Test & Result \\
\hline Tannin & Gelatine test & Negative \\
Saponin & Foam test & Positive \\
Triterpenes & Salkowski reaction & Negative \\
Steroids & Liebermann-Burchard reaction & Negative \\
Phenolics & $\mathrm{FeCl}_{3} 3 \%$ & Positive \\
Flavonoids & Shinoda $(\mathrm{Mg}+\mathrm{HCl})$ & Positive \\
Alkaloids & Dragendorff Reactive & Positive \\
\hline
\end{tabular}

Researcher data.

When representing the mortality of $A$. aegypti larvae as a function of the different dosages of the dried leaves of the mesquite leaf in $\mathrm{g} \mathrm{L}^{-1}$, it is observed that the increase in the dosage is proportional to the increase in the average mortality. It can also be seen that the peak of mortality starts to verticalize in the 
graph from the dosage of $30 \mathrm{~g} \mathrm{~L}^{-1}$, where the mortality efficiency is $62.7 \%$ (Figure 1 ).

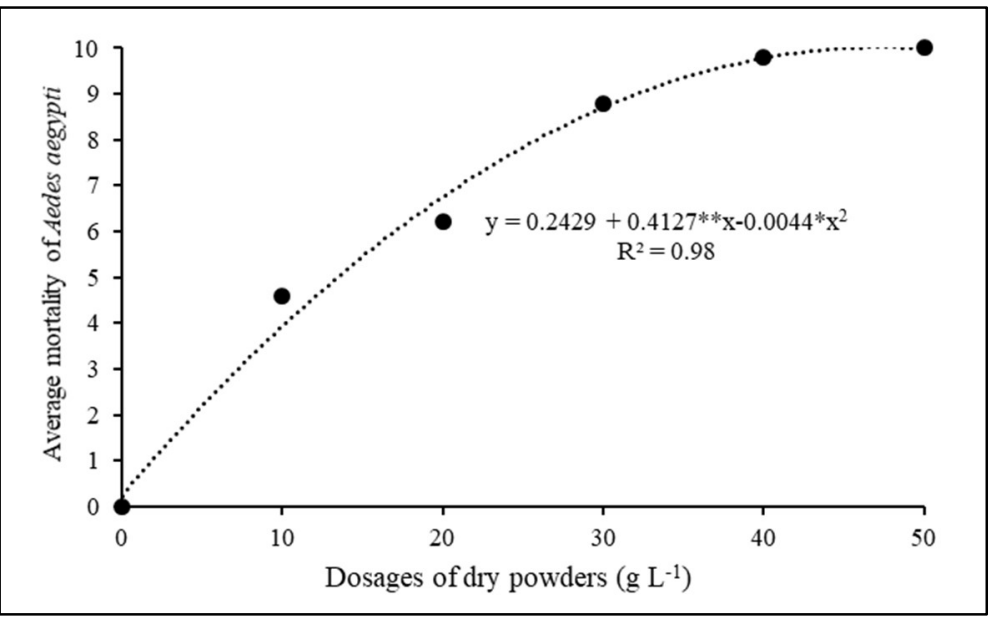

Figure 1: Relationship between larvae mortality of Aedes aegypti under different dosages of the dry powder of the Prosopis juliflora em g/L. Crato-CE, 2018.

\section{DISCUSSION}

Secondary metabolites produced by plants for their defense are an alternative for the control of $A$. aegypti. Several studies with plant extracts have been reported with potential ovicides, larvicides and adulticides on Aedes (GOVINDARAJAN et al., 2011; RAJAN et al., 2012).

The dose of $30 \mathrm{~g} \mathrm{~L}^{-1}$ caused 52 and $60 \%$ mortality, respectively, after 24 and 48 hours of exposure. The doses of 10 and $20 \mathrm{~g} \mathrm{~L}^{-1}$ did not cause $10 \%$ mortality (Table 1 ), having low efficiency during these periods of exposure. This can be explained because the increase in the insect mortality rate is proportional to the increase in the concentration of plant extracts and the exposure period (KEHAIL et al., 2017; DANTAS et al., 2019).

In order to cause $90 \%$ mortality of $A$. aegypti larvae for the exposure periods of 24 and $48 \mathrm{~h}$, it was necessary to apply 63.2 and $128.1 \mathrm{mg} \mathrm{L}^{-1}$ of fresh leaf extract from the mesquite tree, respectively (BANSAL et al., 2012). In order to cause $90 \%$ mortality of $A$. aegypti larvae for the exposure periods of 24 and $48 \mathrm{~h}$, it was necessary to apply 63.2 and $128.1 \mathrm{mg} \mathrm{L}^{-1}$ of fresh leaf extract from the mesquite tree, respectively (BANSAL et al., 2012).

The ether extract of Lantana Câmara and Tridax procumbens promoted 100\% mortality after $48 \mathrm{~h}$. While after $24 \mathrm{~h}$ of exposure the mortality rate was $80.60 \%$, respectively. Analyzing the larvicidal effect of methanolic extracts obtained from Persea americana seed on A. aegypti, Agrela et al. (2014), after 24 hours of exposure of the larvae to the extract in the dosages of 25 and $50 \mathrm{mg} \mathrm{L}^{-1}$, obtained a mortality of $100 \%$ of the larvae.

The extract of the leaves and stem of $P$. juliflora showed significant larvicidal action on third stage larvae of $A$. aegypti (BESERRA et al., 2014), which corroborates the results of this research. These larvicidal effects can be explained by the presence of neurotoxins in plant extracts, since phytochemicals derived from plant sources can act as a larvicide, insect growth regulator and repellent (EICH, 2008).

After $72 \mathrm{~h}$ of exposure, dry powders at 40 and $50 \mathrm{~g} \mathrm{~L}^{-1}$ dosages caused mortality above $90 \%$, even 
eliminating the entire population after $120 \mathrm{~h}$ of exposure at $50 \mathrm{~g} \mathrm{~L}^{-1}$ dosage (Table 1 ). This shows that the dosage of $40 \mathrm{~g} \mathrm{~L}^{-1}$ of the dry powder of the mesquite leaf promotes mortality efficiency similar to that of $50 \mathrm{~g}$ $\mathrm{L}^{-1}$ and can be used in ecological control programs of $A$. aegypti. Plants can be an alternative source like mosquito larvicides because they are a potential source of bioactive chemicals and are generally free of harmful effects to man. The use of these botanical derivatives in mosquito control instead of synthetic insecticides can reduce the cost and environmental pollution.

The growth regulating insecticide pyriproxifene caused mortality after $72 \mathrm{~h}$ of exposure, the morphogenic effects of this insecticide occur mainly in the transition from the larva to pupa phase, where the mechanism is regulated by the increased segregation of the ecdysonium hormone and the absence of the juvenile hormone (INVEST et al., 2008).

Pyriproxifene is a larvicide that has low toxicity to mammals, reduced environmental impact and a long effect of action, to reduce the number of applications and has the particularity of not only interfering in development but also in reproduction (OHBA et al., 2013). The use of pyriproxyphene is particularly suitable for mosquito control, and can be applied in artificial breeding sites or even in water containers intended for human consumption (WHO, 2011).

The lethal doses to cause 50 and $95 \%$ mortality of the larvae $\left(L_{50}\right.$ and $\left.L D_{95}\right)$ were 29.8 and $49.9 \mathrm{~g} \mathrm{~L}^{-1}$ of water respectively. For aqueous extracts of $P$. juliflora leaves at dosages of 10, 20, 50, 100 and 200 ppm, an $L_{50}$ of 126.79 and $L C_{90}$ of 457.32 ppm were found for this vector (TYAGl et al., 2015). For the plant extracts of Artemisia herba alba on larvae of $A$. aegypti, $\mathrm{LC}_{50}$ of 542.5 and $\mathrm{LC}_{90}$ of 1,214.0 ppm were found respectively and for Matricharia chamomilla extract of 142.1 and 325.8 ppm (MAHYOUB et al., 2014).

The vegetable extract from Lantana Câmara showed an $\mathrm{LC}_{50}$ of less than $220 \mathrm{mg} \mathrm{ml}^{-1}$. The $\mathrm{LC}_{50}$ of Ageratina adenophora in A. aegypti was found in $50 \mu \mathrm{g} \mathrm{mL}^{-1}$ (RAJMOHAN et al., 2007). Rubia cordifolia root extract registered larvicidal activity with $\mathrm{LC} 50$ and $\mathrm{LC}_{90}$ values of 102.2 and $350.2 \mathrm{mg} \mathrm{L}^{-1}$ against $A$. aegypti larvae, respectively (MUNUSAMY et al., 2016).

Larvicidal activity of $10 \%$ mesquite leaf extracts was effective with an $\mathrm{LC}_{50}$ of $9.3 \mathrm{mg} \mathrm{L}^{-1}$ against $A$. stephensi larvae (SENTHILKUMAR et al., 2009). It's notable that the larvicidal activity of the extract of this plant is variable in different studies. The reason for this variation may be due to the part of the plant used, the geographical location of the plant, photosensitivity of some metabolites, the extraction solvent and the extraction process and, finally, the species responses to the specified extracts (SENTHILKUMAR et al., 2009).

Research has been reported regarding the susceptibility of $A$. aegypti larvae to a wide variety of plant extracts under laboratory conditions, however this susceptibility is dependent on the applied extract dose and the species of plant used (KAUSHIK et al., 2009). The biological properties of these plant extracts may be due to numerous chemical compositions, including phenolics, terpenoids, flavonoids and alkaloids. These constituents can contribute jointly or independently to produce toxic activity against mosquito species (KAMARAJ et al., 2011; MOHANKUMAR et al., 2016).

The dosages of 10 and $20 \mathrm{~g}$ were less efficient and did not differ statistically from each other, with pyriproxifene being more efficient than the same ones, killing an average of 8 larvae/pupae (Table 4). 
Pyriproxyphene does not kill mosquito larvae directly, but it interrupts the normal process of insect development in the fourth larval instar for the beginning of the pupa phase, which leads to pupal mortality and prevention of the emergence of adult mosquitoes (RESENDE et al., 2006).

Table 4: Average number of dead Aedes aegypti larvae submitted to different dosages of the post-dry leaf of Prosopis juliflora, compared to the chemical insecticide pyriproxifene, after seven days of exposure, Crato-CE, 2018.

\begin{tabular}{lll}
\hline Treatments & Dosages $(\mathrm{g})$ & Average dead larvae $^{1}$ \\
\hline Distilled water & 0 & 0 \\
Pyriproxifene & 0.01 & $8.0 \mathrm{a}$ \\
Dry leaf powder & 10 & $4.6 \mathrm{~b}$ \\
Dry leaf powder & 20 & $6.2 \mathrm{~b}$ \\
Dry leaf powder & 30 & $8.8 \mathrm{a}$ \\
Dry leaf powder & 40 & $9.8 \mathrm{a}$ \\
Dry leaf powder & 50 & $10 \mathrm{a}$ \\
\hline C.V. (\%) & & 14.12
\end{tabular}

${ }^{1}$ Means followed by the same letter in the columns, do not differ significantly by the tukey test at the $5 \%$ probability level. C.V=Coefficient of variation.

The results of the phytochemical prospecting of the aqueous extract of the dry powder of the mesquite leaf indicate the presence of the metabolites saponin, phenolic, flavonoids and alkaloids. The piperidine alkaloids, isolated from the leaves and fruits of this plant are referred to as the most important pharmacologically active compounds, having been tested in different biological systems, being attributed to the therapeutic activities conferred to the plant (SINGH et al., 2012). In addition, it also has anthelmintic activity (BATATINHA et al., 2011) and is an inhibitor of acetylcholinesterase and butyrylcholinesterase, with $\mathrm{Ca}^{2+}$ channel blocking activity (CHOUDHARY et al., 2005) which can cause mortality to A. aegypti.

The increase in mortality of $A$. aegypti larvae is proportional to the increase in the dose of $P$. juliflora extract. The crude extract obtained from different parts of the Ipomoea cairica plant demonstrated late larvicidal activity in the third stage of A. albopictus and $A$. aegypti under laboratory conditions. The increase in the dosages of crude extracts caused a proportional increase in the average mortality of the larvae (AHBIRAMI et al., 2014). No mortality was recorded at a concentration of $10 \mathrm{ppm}$. At the highest concentration (450 ppm) that induced 100\% mortality, the larvae reacted with behavioral changes, such as agitated movements for some time, followed by slowness, convulsions and subsequent paralysis at the bottom of the beakers and died slowly (AHBIRAMI et al., 2014).

\section{CONCLUSIONS}

The dosages of 40 and $50 \mathrm{~g} \mathrm{~L}^{-1}$ of the dry powder of $P$. juliflora leaves are efficient in the mortality of A. aegypti larvae after $48 \mathrm{~h}$ of exposure, with greater efficiency after $120 \mathrm{~h}$, causing $100 \%$ mortality.

The lower dosages $\left(10\right.$ and $\left.20 \mathrm{~g} \mathrm{~L}^{-1}\right)$ have low efficiency in mortality and the dosage of $30 \mathrm{~g} \mathrm{~L}^{-1}$ causes satisfactory mortality after $120 \mathrm{~h}$ of exposure. P. juliflora dry powder has the potential to be used in the ecological control of A. Aegypti, however it is necessary to characterize and quantify the constituents of the plant extract followed by bioassays under field conditions, since it was carried out in the laboratory.

ACKNOWLEDGEMENTS: To the National Council for Scientific and Technological Development (CNPq) and to 
the Person Coordination of highter Education (CAPES), respectively for the project financing and for the concessions of the scholarships. For this type of study formal consent is not required. All authors have read and approved this manuscript to be sent and published in this journal. All authors participated fully in the entire process of building this article. All authors agree with the process of processing this article in this journal and subsequently publication. All authors have effectively built on this article and agree with the submission and publication process.

\section{REFERENCES}

ABBOTT, W. S.. A method of computing the effectiveness of on insecticide. Journal Economic Entomology, v.18, p.265267, 1925. DOI: https://doi.org/10.1093/jee/18.2.265a

AHBIRAMI, R.; ZUHARAH, W. F.; THIAGALETCHUMI, M.; SUBRAMANIAM, S.; SUNDARASEKAR, J.. Larvicidal efficacy of different plant parts of railway creeper, Ipomoea cairica Extract Against Dengue Vector Mosquitoes, Aedes albopictus (Diptera: Culicidae) and Aedes aegypti (Diptera: Culicidae). Journal of Insect Science, v.14, p.180-189, 2014. DOI: https://doi.org/10.1093/jisesa/ieu042

AGRELA, I. F.; HIDALGO, Y.; HERRERA, F. Efecto larvicida de extractos metanólicos obtenidos de semillas y hojas de Persea americana (Laurales: Lauraceae) (aguacate) sobre Aedes aegypti (Diptera: Culicidae). Boletín de Malariología y Salud Ambiental, 54: 199-207, 2014. DOI: https://pesquisa.bvsalud.org/portal/resource/pt/lil-740286

BANSAL, S. K.; SINGH, K. V.; SHARMA, S.; SHERWANI, M. R. K.. Laboratory observations on the larvicidal efficacy of three plant species against mosquito vectors of malaria, Dengue/Dengue Hemorrhagic Fever (DF/DHF) and lymphatic filariasis in the semiarid desert. Journal of Environmental Biology, v.33, p.617-621, 2012.

BATATINHA, M. J. M.; ALMEIDA, G. N.; DOMINGUES, L. F.. Efeitos dos extratos aquoso e metanólico de algaroba sobre culturas de larvas de nematódeos gastrintestinais de caprinos. Ciência Animal Brasileira, v.12, p.514-519, 2011. DOI: https://doi.org/10.5216/cab.v12i3.3653

BENNETT, K. L.; GÓMEZ-MARTÍNEZ, C.; CHIN, Y.; SALTONSTAL, K.; MCMILLAN, W. O.; ROVIRA, J. R.; LOAIZA, J. R.. Dynamics and diversity of bacteria associated with the disease vectors Aedes aegypti and Aedes albopictus.

Scientific Reports, v.9, p.1-12, 2019. DOI:

https://doi.org/10.1038/s41598-019-48414-8

BESERRA, F. P.; AGUIAR, R. W. S.; CARVALHO, E. E. N.; BORGES, J. C. M.; VALE, B. N.. Atropha curcas L.

(Euphorbiáceae) como novo bioinseticida: análise fitoquímica preliminar e atividade larvicida contra Aedes aegypti (Diptera: culicidae). Revista Amazônia Science \& Health, v.2, p.17-25, 2014.

CHAPMAN, D.; STARFIGER, U.; PESCOTT, O. L.. Prosopis juliflora (Sw.). OEPP/EPPO Bulletin, v.49, p.290-297, 2019.

CHOUDHARY, M. I.; NAWAZ, S. A.; ZAHEER-UI-HAQ, A. M. K.; GHAYUR, M. N.; LODHI, M. A.; JALIL, S.. Juliflorine: a potent natural peripheral anionic-site-binding inhibitor of acetylcholinesterase with calcium-channel blocking potential, a leading candidate for Alzheimer's disease therapy. Biochemical and Biophysical Research Communications, v.332, p.1171-1177, 2005. DOI: https://doi.org/10.1016/j.bbrc.2005.05.068

DANTAS, J. O.; ARAÚJO-PIOVEZAN, T. G.; SANTOS, D. P.; ALVES, A. E. O.; PINHEIRO, S. S. C.; RIBEIRO, G. T.. Extracts of Potential Plants in the Control of the Aedes aegypti Population.Ensaios e Ciência, v.23, p.104-108, 2019. DOI: https://doi.org/10.17921/1415-6938.2019v23n2p104-108

EICH, E.. Solanaceae and convolvulaceae: secondary metabolites: biosynthesis, chemotaxonomy, biological and economic significance (a handbook). Berlin Heidelberg: Springer-Verlag, 2008. DOI: https://doi.org/10.1007/978-3540-74541-9

ESTRADA, J. L. T.; MOSCOSO, K. E. P.; SALAS, I. F.; ACHEE, N. L.; GRIECO, J. P.. Spatial repellency and other effects of transfluthrin and linalool on Aedes aegypti and Aedes albopictus. Journal of Vector Ecology, v.44, p.89-93, 2019. DOI: https://doi.org/10.1111/jvec.12332

GOVINDARAJAN, M.; KARUPPANNAN, P.. Mosquito larvicidal and ovicidal properties of Eclipta alba (L.) Hassk (Asteraceae) against chikungunya vector, Aedes aegypti (Linn.) (Diptera: Culicidae). Asian Pacific Journal of Tropical Biomedicine, v.4, p.24-28, 2011. DOI: https://doi.org/10.1016/S19957645(11)60026-6

INVEST, J. F.; LUCAS, J. R.. Pyriproxyfen as a mosquito larvicide. In: ROBINSON, W. H.; BAJOMI, D.. Proceedings of the Sixth International Conference on Urban Pests. 2008. p.239-246.

KAMARAJ, C.; BAGAVAN, A.; ELANGO, G.; ZAHIR, A. A.; RAJAKUMAR, G.; MARIMUTHU, S.. Larvicidal activity of medicinal plant extracts against Anopheles subpictus \& Culex tritaeniorhynchus. The Indian Journal of Medical Research, v.134, p.101-106, 2011.

KAUSHIK, R.; SAINI, P.. Screening of some semi-arid region plants for larvicidal activity against Aedes aegypti mosquitoes. Journal of Vector Borne Diseases, v.46, p.244246, 2009.

KEHAIL, M. A. A.; BASHIR, N. H. H.; ABDELRAHMAN, E. E.; ABDELRAHIM, A. M.. Larvicidal activity of three plants powders and aqueous extracts on Anopheles and Culex mosquito larvae (Diptera: Culicidae). International Journal of Mosquito Research, v.4, p.37-41, 2017. 
LINDSAY, S. W.; WILSON, A.; GOLDING, N.; SCOTT, T. W.; TAKKEN, W.. Improving the built environment in urban areas to control Aedes aegypti borne diseases. Bull World Health Organ., v.95, p.607-608, 2017. DOI: https://doi.org/10.2471/BLT.16.189688

MAHYOUB, J. A.; AI-MEHMADI, R. M.; AMAL, H.; ABUKHAMMAS, A.; AZIZ, A. T.; Al-SHAMI, A. S.. The Effect of Some Plant Extracts on Mosquito Aedes aegypti (L.). Biosciences Biotechnology Research Asia, v.11, p.1-9, 2014. DOI: https://doi.org/10.13005/bbra/1498

MOHANKUMAR, T. K.; SHIVANNA, K. S.; ACHUTTAN, V. V.. Screening of methanolic plant extracts against larvae of Aedes aegypti and Anopheles stephensi in Mysore. Journal of Arthropod Borne Diseases, v.10, p.303-314, 2016

MUNUSAMY, R. G.; APPADURAI, D. R.; KUPPUSAMY, S.; MICHAEL, G. P.; SAVARIMUTHU, I.. Ovicidal and larvicidal activities of some plant extracts against Aedes aegypti L. and Culex quinquefasciatus Say (Diptera: Culicidae). Asian Pacific Journal of Tropical Disease, v.6, p.468-471, 2016. DOI: https://doi.org/10.1016/S2222-1808(16)61070-8

OHBA, S.; OHASHI, K.; PUIIYATI, E.; HIGA, Y.; KAWADA, H.; MITO, N.; TAKAGI, M.. The effect of pyriproxyfen as a "population growth regulator" against Aedes albopictus under semi-field conditions. PloS, v.8, p.e67045, 2013. DOI: https://doi.org/10.1371/journal.pone.0067045

PASIECZNIK, N. M.; FELKER, P.; HARRIS, P. J. C.; HARSH, L. N.; CRUZ, G.; TEWARI, J. C.. The Prosopis juliflora - Prosopis pallida Complex: A Monograph. Coventry: HDRA, 2001.

POLANCZYK, R. A.; GARCIA, M. O.; ALEVES, S. B.. Potencial de Bacillus thuringiensis israelensis Berliner no controle de Aedes aegypti. Revista de Saúde Pública, v.37, n.6, p.813816, 2013.

RAJMOHAN, D.; RAMASWAMY, M.. Evaluation of larvicidal activity of the leaf extract of a weed plant, Ageratina adenophora against two important species of mosquito $A$. aegypti \& C. quinqufaciatues. Biotechnology, v.6, p.631-638, 2007.

RAJAN, M.; SAVARIMUTHU, I.. A novel herbal formulation against dengue vector mosquitoes Aedes aegypti and Aedes albopictus. Parasitology Research, v.110, p.1801-1813, 2012. DOI: https://doi.org/10.1007/s00436-011-2702-z
RESENDE, M. C.; GAMA, R. A.. Persistência e eficácia do regulador de crescimento pyriproxyfen em condições de laboratório para Aedes aegypti. Revista da Sociedade Brasileira de Medicina Tropical, v.39, p.72-75, 2006. DOI: https://doi.org/10.1590/\$0037-86822006000100014

RIBASKI, J.; DRUMOND, M. A.; OLIVEIRA, V. R.; NASCIMENTO, C. E. S.. Algaroba (Prosopis juliflora): Árvore de uso Múltiplo para a Região Semiárida Brasileira. Colombo: Embrapa Florestas, 2009.

ROIZ, D.; WILSON, A. L.; SCOTT, T. W.; FONSECA, D. M.; JOURDAIN, F.; MULLER, P.. Integrated Aedes management for the control of Aedes-borne diseases. PLoS Neglected Tropical Dieases, v.12, p.e0006845, 2018. DOI: https://doi.org/10.1371/journal.pntd.0006845

SCOLARI, F.; CASIRAGHI, M.; BONIZZONI, M.. Aedes spp.and Their Microbiota: A Review. Frontiers in Microbiology, v.10, p.2036, 2019.

SENTHILKUMAR, N.; VARMA, P.; GURUSUBRAMANIAN, G. Larvicidal and adulticidal activities of some medicinal plants against the malarial vector, Anopheles stephensi (Liston) Parasitology Research, v.104, p.237-244, 2009. DOI: https://doi.org/10.1007/s00436-008-1180-4

SINGH, A.; VERMA, S. K.. Study of the distribution profile of piperidine alkaloids in various parts of Prosopis juliflora by the application of direct analysis in real time mass spectrometry (DART-MS). Natural Products and Bioprospecting, v.2, p.206-209, 2012. DOI: https://doi.org/10.1007/s13659-012-0069-1

TYAGI, V.; YADAV, R.; SUKUMARAN, D.; VEER, V.. Larvicidal activity of invasive weed Prosopis juliflora against mosquito species Anopheles subpictus, Culex quinquefasciatus and Aedes aegypti. International Journal of Applied Research, v.1, p.285-288, 2015.

VARUN, T.; RUCHI, Y.; KUMAR, S. A.; VIVEK, T.; SHWETA, Y.; VEER, V.; DEVANATHAN, S.. Larvicidal activity of leaf extract of some weeds against malaria vector Anopheles stephensi. International Journal of Malaria Research and Reviews, v.1, p.35-39, 2013.

WHO. World Health Organization. Global insecticide use for vector-borne disease control: a 10-year assessment (20002009). 5 ed. Geneva: WHO, 2011.

A CBPC - Companhia Brasileira de Produção Científica (CNPJ: 11.221.422/0001-03) detém os direitos materiais desta publicação. Os direitos referem-se à publicação do trabalho em qualquer parte do mundo, incluindo os direitos às renovações, expansões e disseminações da contribuição, bem como outros direitos subsidiários. Todos os trabalhos publicados eletronicamente poderão posteriormente ser publicados em coletâneas impressas sob coordenação da Sustenere Publishing, da Companhia Brasileira de Produção Científica e seus parceiros autorizados. Os (as) autores (as) preservam os direitos autorais, mas não têm permissão para a publicação da contribuição em outro meio, impresso ou digital, em português ou em tradução. 